\title{
Model Pembelajaran Group Investigation (GI) Untuk Meningkatan Prestasi Belajar Mata Pelajaran IPA Kelas V
}

\author{
Sulistiodiono
}

Guru SDN 1 Ngembel Trenggalek

Email: sdn-1-ngembel@yahoo.com

\begin{tabular}{l}
\hline Tersedia Online di \\
http://www.jurnal.unublitar.ac.id/ \\
index.php/briliant \\
\hline
\end{tabular}

Sejarah Artikel

Diterima pada 29 Juni 2017

Disetuji pada 10 Juli 2017

Dipublikasikan pada: 2 Agustus

2017 Hal 312-318

Kata Kunci:

Group Investigation, Model,

Prestasi, IPA

\begin{abstract}
Abstrak: Tujuan penelitian ini untuk mengetahui peningkatan prestasi belajar IPA Materi Tumbuhan Hijau melalui model pembelajaran Group Investigation (GI) bagi siswa kelas V Semester I Tahun Pelajaran 2015/2016 di SDN 1 Ngembel Kecamatan Watulimo Kabupaten Trenggalek. Model pembelajaran Group Investigation (GI) meningkatkan prestasi belajar IPA pada siswa kelas V semester I tahun pelajaran 2014/2015 di SDN 1 Ngembel Kecamatan Watulimo Kabupaten Trenggalek, siklus I mencapai $82 \%$ dan siklus II naik menjadi $88 \%$ dengan nilai rata-rata kelas siklus I mencapai 78 dan siklus II naik menjadi 85.
\end{abstract}

Mata pelajaran Ilmu Pengetahuan Alam (IPA) merupakan mata pelajaran yang mengantisipasi berbagai perkembangan yang terjadi dalam dunia global. Mata pelajaran Ilmu Pengetahuan Alam (IPA) menghendaki agar siswa lulusan sekolah mempunyai ketrampilan scientific. Dalam era globalisasi, diperlukan adanya tenaga-tenaga terlatih, yang dapat menguasai konsep Ilmu Pengetahuan Alam (IPA) dalam kehidupannya, sehingga kemajuan teknologi dan informasi dapat diikuti perkembangannya. Arus globalisasi yang sarat dengan arus informasi merupakan tantangan yang harus dihadapi.

Metode pembelajaran yang monoton yang kurang bervariasi dan kurang mengaktifkan siswa. Guru seringkali menjadi "Single Actor" dalam kegiatan pembelajaran di kelas. Guru cenderung menggunakan metode mengajar dengan cara ceramah, sehingga komunikasi hanya berlangsung satu arah saja. Siswa hanya aktif mendengarkan dan sesekali menjawab pertanyaan guru. Siswa kurang bergairah dalam belajar, pasif dan tidak dituntut untuk menunjukkan kretifitasnya.

Beberapa masalah yang dimungkinkan menyebabkan rendahnya prestasi belajar siswa adalah sebagian siswa tidak terlihat aktif dalam pembelajaran, guru kurang memotivasi siswa, media pembelajaran yang kurang lengkap dan kurang menarik. Sehubungan dengan hal tersebut di atas, maka untuk meningkatkan kualitas pembelajaran perlu kiranya dilakukan suatu tindakan dari guru untuk merubah pola pembelajaran dengan menggunakan berbagai model pembelajaran. Salah satu upaya yang kemungkinan dapat dijadikan sebagai alternatif dalam memecahkan masalah sebagaimana yang disampaikan di atas adalah menggunakan model pembelajaran "Group Investigation (GI)". Dengan demikian diharapkan siswa benar-benar termotivasi dalam mencapai prestasi belajarnya. 
Prestasi belajar merupakan penilaian hasil usaha kegiatan belajar dalam bentuk simbul, angka, huruf, maupun kalimat yang dapat mencerminkan hasil yang sudah dicapai oleh setiap anak dalam periode tertentu (Muhammad Fathurrohman, 2012:119). Prestasi menurut Kamus Lengkap Bahasa Indonesia adalah hasil baik yang dicapai (Fajri, 2008:670). Sedangkan belajar dikatakan sebagai proses di mana tingkah laku ditimbulkan atau diubah melalui latihan atau pengalaman (Djamarah,2011:12)

Belajar sebagai proses, baik bersifat proses waktu maupun proses mental dan emosional, membawa perubahan pada diri seseorang. Belajar merupakan suatu bentuk pertumbuhan atau perubahan dalam diri seseorang yang dinyatakan dalam cara-cara bertingkahlaku yang baru berkat pengalaman dan latihan (Aqib, 2012:42). Fahturrohman (2012:121) faktor-faktor yang mempengaruhi belajar adalah faktor internal (aspek fisiologis dan aspek psikologis), dan faktor Eksternal (faktor lingkungan sosial dan faktor lingkungan non sosial.

Seluruh aktifitas belajar siswa adalah untuk mendapatkan prestasi belajar yang baik, setiap siswa berlomba-lomba untuk mencapainya dengan suatu usaha yang dilakukan seoptimal mungkin dengan demikian maka prestasi belajar dapat dikatakan sebagai kebutuhan yang memunculkan motivasi dari dalam diri siswa untuk selalu belajar (Djamarah, 2012:28). Upaya untuk menghadapi berbagai kesulitan yang mungkin muncul dalam kegiatan belajar dilakukan dengan memahami cara memotivasi dalam belajar. Cara memotivasi belajar siswa adalah dengan cara memegang prinsip-prinsip kebermaknaan, modeling, komunikasi terbuka, prasyarat, novelty (baru), latihan/praktek yang aktif dan bermanfaat, latihan terbagi, kurangi secara sistematik paksaan belajar, dan kondisi yang menyenangkan (Hamalik, 2001: 156-161). Materi dianggap bermakna apabila materi tersebut memiliki hubungan pengajaran dengan pengalaman para siswa dan hubungan pengajaran dengan minat dan nilai siswa.

Hamzah (2008:23), motivasi dalam kegiatan belajar merupakan dorongan baik yang bersifat internal maupun eksternal untuk melakukan kegiatan belajar. Adanya dorongan tersebut membuat siswa mempunyai kemauan untuk belajar. Sedangkan aplikasi dari kegiatan belajar tersebut akan terlihat hasilnya apabila ada perubahan perilaku. Jadi perubahan tersebut tidak akan terjadi jika tidak ada dorongan untuk merubahnya.

Belajar Ilmu Pengetahuan Alam (IPA) adalah belajar untuk membentuk kepribadian yang kuat dan berakhlaq mulia, dengan memperbesar rasa syukur kepada Tuhan Yang Maha Esa. Pengembangan kemampuan siswa dalam bidang Ilmu Pengetahuan Alam (IPA) merupakan salah satu kunci keberhasilan peningkatan kemampuan dalam menyesuaikan diri dengan perubahan dan memasuki dunia teknologi, termasuk teknologi informasi. Untuk kepentingan pribadi, sosial, ekonomi dan lingkungan, siswa perlu dibekali dengan kompetensi yang memadai agar dapat berperan aktif dalam masyarakat (Dinas Pendidikan dan Kebudayaan, 2006:2)

Kurikulum Ilmu Pengetahuan Alam (IPA) merupakan kurikulum yang membantu siswa untuk memilih karir yang tepat. Dengan cara kerja ilmiah yang terbiasa dilakukan oleh pola pikir Ilmu Pengetahuan Alam (IPA), memungkinkan siswa dapat bersikap ilmiah pula pada dirinya, sehingga dapat menentukan karir yang tepat dan sesuai dengan kemampuannya. Pendidikan Ilmu Pengetahuan Alam IPA) menekankan pada pemberian pengalaman langsung untuk 
mengembangkan kompetensi agar siswa mampu menjelajahi dan memahami alam sekitar secara ilmiah. Pendidikan Ilmu Pengetahuan Alam (IPA) diarahkan untuk "mencari tahu" dan "berbuat" sehingga dapat membantu siswa untuk memperoleh pemahaman yang lebih mendalam tentang alam sekitar". (Dinas Pendidikan dan Kebudayaan, 2006:2)

Maka dari itu peneliti seperti dikatakan sebelumnya, mengusulkan penerapan model pembelajaran kooperatif tipe Group Investigation. Wiratamam menjelaskan model pembelajaran Group Investigation (GI) merupakan metode pembelajaran dengan siswa belajar secara kelompok, kelompok belajar terbentuk berdasarkan topik yang dipilih siswa. Pendekatan ini memerlukan norma dan struktur yang lebih rumit daripada pendekatan yang lebih berpusat pada guru. Dalam pembelajaran kooperatif GI siswa dibagi menjadi beberapa kelompok dengan anggota 2-6 orang siswa yang heterogen. Kelompok memilih topik untuk diselidiki dan melakukan penyelidikan yang mendalam atas topik yang dipilih, selanjutnya menyiapkan dan mempresentasikan laporan di depan kelas. Selanjutnya Shoimin menjelaskan Group Investigation (GI) adalah suatu model pembelajaran yang lebih menekankan pada pilihan dan kontrol siswa daripada menerapkan teknik-teknik pengajaran diluar kelas. Selain itu juga memadukan prinsip belajar demokratis dimana siswa terlibat secara aktif dalam kegiatan pembelajaran, baik dari tahap awal sampai akhir pembelajarn termasuk di dalamnya siswa mempuyai kebebasan untuk memilih materi yag akan dipelajari sesuai dengan topik yang sedang dibahas (Aris Shoimin, 2014:80).

Langkah-langkah model pembelajaran Group Investigation adalah guru membagi kelas menjadi beberapa kelompok yang heterogen, guru menjelaskan maksud pembelajaran dan tugas kelompok yang harus dikerjakan, guru mengundang ketua-ketua kelompok untuk mengambil materi tugas, masingmasing kelompok membahas materi tugas secara kooperatif dalam kelompoknya, setelah selesai, masing-masing kelompok yang diwakili ketua kelompok atau salah satu anggotanya menyampaikan hasil pembahasan, kelompok lain dapat memberikan tanggapan terhadap hasil pembahasan, guru memberikan penjelasan singkat (klarifikasi) bila terjadi kesalahan konsep dan memberikan kesimpulan, dan evaluasi (Aris Shoimin, 2014:81).

Dengan demikian penelitian ini bertujuan untuk melihat bagaimana penerapan GI pada pembelajaran IPA serta dampaknya terhadap prestasi siswa. Sehingga melalui penelitian ini akan diketahui peningkatan prestasi belajar IPA Materi Tumbuhan Hijau bagi siswa sekolah dasar kelas V. Khususnya di SDN 1 Ngembel Kecamatan Watulimo Kabupaten Trenggalek.

\section{METODE}

Penelitian ini merupakan Penelitian Tindakan kelas (PTK) atau Classroom Action Research, suatu pencermatan terhadap kegiatan belajar berupa suatu tindakan, yang sengaja dimunculkan dan terjadi dalam suatu kelas secara bersama (Arikunto, 2011:3). Masing-masing siklus melalui 4 (empat) tahap yakni perencanaaan, pelaksanaan, pengamatan, refleksi. Peneliti sekaligus guru terlibat penuh dalam penelitian, bekerjasama dengan rekan kerja (kolaborator) sehingga dapat memaksimalkan temuan dan kajian selama penelitian berlangsung. Penelitian mengambil subjek siswa kelas V SDN 1 Ngembel Kecamatan

314 BRILIANT: Jurnal Riset dan Konseptual Volume 2 Nomor 3, Agustus 2017 
Watulimo Kabupaten Trenggalek semester I tahun pelajaran 2015/2016 yang berjumlah 17 siswa, terdiri dari 9 siswa laki-laki dan 8 siswa perempuan.

Instrumen penelitian menggunakan test dan lembar pengamatan/lembar observasi. Penyusunan soal test untuk menentukan tujuan, membuat kisi-kisi soal, dan membuat soal test isian. Lembar observasi yang dipergunakan pada siklus I dan siklus II dipergunakan untuk melihat kemajuan siswa. Data berupa hasil observasi langsung tentang aktifitas siswa dalam pembelajaran di setiap siklusnya, serta data tentang prestasi belajar siswa. Metode pengumpulan data yang dipergunakan adalah test dan non tes yang berupa pengamatan (observasi).

Data hasil observasi dianalisis berdasarkan prosentase yang ditetapkan, dan dianalisis berdasarkan pada ketuntasan belajar siswa. Setelah diketahui skor yang diperoleh siswa, kemudian diolah menjadi nilai akhir, maka hasil tersebut dikomunikasikan dengan nilai KKM yang ada dan dibandingkan dengan hasil belajar sebelumnya. Perbandingan hasil test siklus I dan siklus II memberikan kejelasan penggunaan model pembelajaran Group Investigation (GI.

Untuk menganalisisnya dengan langkah menyusun tabel penilaian, enghitung skor setiap individu dengan rumus:

$$
\mathrm{NA}=\frac{\text { SkorPerolehan }}{\text { SkorMaksimal }} \times 100
$$

Menghitung persentase peningkatan hasil belajar, dengan rumus NP = (Rs - Rd) x 100\%, keterangan: $\mathrm{NP}=$ prosentase kenaikan, $\mathrm{S}=$ jumlah skor yang diperoleh siswa, dan $\mathrm{Rd}=$ Skor rata-rata siklus sebelumnya, dan selanjutnya embuat grafik sebaran nilai sebagai langkah ntuk menafsirkan peningkatan aktifitas siswa.

\section{HASIL}

\section{Pra Siklus}

Pada tahap pra siklus perencanaan penelitian dengan melakukan menyiapkan silabus, menyiapkan RPP, menyiapkan media pembelajaran, menyiapkan LKS, menyiapkan instrument penilaian yaitu lembar tes uraian, dan menyiapkan instrument penilaian yaitu lembar observasi. Paksanaan selama kegiatan pembelajaran, peneliti sekaligus praktisi melakukan kegiatan pembelajaran sesuai dengan rencana yang telah disiapkan.

Hasil tes pada pra siklus ini, jumlah siswa yang menjadi subjek penelitian adalah 17siswa, tuntas dalam belajar (nilai minimal sama dengan KKM yakni 70), sebanyak 11 siswa (65\%) dan jumlah siswa yang tidak tuntas sebanyak 6 siswa (35\%). Selanjutnya, dari 17 siswa tersebut dikelompokkan menjadi kategori sangat baik sebanyak 1 siswa (6\%), kategori baik sebanyak 4 siswa (24\%), kategori lebih dari cukup sebanyak 4 siswa (24\%), kategori cukup sebanyak 2 siswa (12\%), dan kategori kurang sebanyak 6 siswa (35\%). Hasil kajian rata-rata yang dapat dicapai oleh siswa 74, modus berada pada nilai kurang dari 70 sebanyak 6 siswa (35\%), secara kajian menunjukkan 9 siswa (53\%) siswa aktif dan 8 siswa (47\%) siswa pasif.

Refleksi dari pelaksanaan pra siklus terdapat kajian siswa yang aktif dalam diskusi masih rendah, guru belum memvariasikan metode pembelajaran yang dipergunakan sehingga terkesan monoton, dan guru kurang memberikan motivasi kepda siswa pada saat proses pembelajaran berlangsung, termasuk pada saat melaksanakan diskusi kelompok . 


\section{Siklus I}

Pada siklus I ini kegiatan pembelajaran praktisi menyusun RPP dengan menggunakan model pembelajaran "Group Investigation (GI)". Pertemuan 1, tahap perencanaan, peneliti mengatur strategi dengan menyiapkan silabus, mengembangkan skenario pembelajaran, menyiapkan sumber dan media pembelajaran, menyusun LKS, menyusun instrument soal test, dan menyusun format observasi pembelajaran sesuai model. Pelaksanaan dilakukan dengan menerapkan langkah-langkah pembelajaran disesuaikan model pembelajaran "Group Investigation (GI)". Pembelajaran model Group Investigation (GI berlangsung sesuai dengan RPP yang telah disiapkan, hasil pengamatan dengan menggunakan lembar observasi siswa menunjukkan 11 siswa aktif dan 6 siswa pasif. Dengan demikian ada $65 \%$ siswa aktif dan $35 \%$ siswa pasif. Pertemuan 2, tahap perencanaan, peneliti mengatur strategi dengan memperbaiki kendala pada siklus 1. Pelaksanaan dilakukan dengan menerapkan langkah-langfkah pembelajaran yang berlangsung sesuai dengan RPP yang telah disiapkan, dan telah melaksanakan pembelajaran dengan model Group Investigation (GI). Hasil pengamatan siswa menunjukkan 11 siswa aktif dan 6 siswa pasif atau ada $65 \%$ siswa aktif dan $35 \%$ siswa pasif.

\section{Siklus II}

Pada siklus II ini penyusunan RPP model pembelajaran "Group Investigation (GI)" dipebaiki sesuai dengan hasil refleksi pada siklus I. Pertemuan 1, pada tahap perencanaan, peneliti mengatur strategi yang dilakukan pada tahap pelaksanaan dengan menerapkan model pembelajaran "Group Investigation" (GI). Pembelajaran berlangsung sesuai dengan RPP pembelajaran dengan model Group Investigation (GI). Hasil observasi menunjukkan 14 siswa aktif dan 3 siswa pasif, dengan demikian ada $82 \%$ siswa aktif dan $18 \%$ siswa pasif. Pertemuan 2, tahap perencanaan, peneliti mengatur strategi dengan menerapkan model pembelajaran Group Investigation (GI), sebagaimana telah diterapkan pada siklus I. Pembelajaran berlangsung sesuai dengan RPP pembelajaran dengan model Group Investigation (GI). Hasil observasi menunjukkan 16 siswa aktif dan 1 siswa pasif, dengan demikian ada $94 \%$ siswa aktif dan $6 \%$ siswa pasif.

\section{PEMBAHASAN}

\section{Siklus I}

Jumlah siswa yang menjadi subjek penelitian 17, siswa yang tuntas dalam belajar (nilai minimal sama dengan KKM yakni 70) sebanyak 14 siswa $(82 \%)$ dan jumlah siswa yang tidak tuntas sebanyak 3 siswa (18\%). Selanjutnya, dari 17 siswa tersebut dikelompokkan kategori sangat baik sebanyak 3 siswa (18\%), kategori baik sebanyak 2 siswa (12\%), kategori lebih dari cukup sebanyak 4 siswa (24\%), kategori cukup sebanyak 5 siswa (29\%), dan kategori kurang sebanyak 3 siswa (18\%). Sehingga rata-rata yang dapat dicapai oleh siswa 78, modus berada pada nilai kurang dari 70 sebanyak 3 siswa (18\%). Hasil kajian baik pada pertemuan I dan pertemuan II menunjukkan 11 siswa (65\%) siswa aktif dan 6 siswa (35\%) siswa pasif. Hasil refleksi yang diperoleh dari pelaksanaan siklus I penggunaan metode Group Investigation (GI) sebenarnya sangat merangsang 
siswa, namun terkesan belum efektif karena siswa masih terlihat kurang paham dalam melakukannya sehingga masih banyak bertanya, interaksi dalam kelompok masih kurang maksimal, dan hasil tes yang dilakukan pada siklus I menunjukkan adanya peningkatan baiik pada tingkat ketuntasan siswa maupun pada rata-rata kelas, jika dibandingkan dengan hasil tes pada pra siklus. Namun karena pelaksaaan model pembelajaran Group Investigation (GI) terasa masih belum maksimal, maka peneliti memutuskan untuk melanjutkan pada siklus II, dan diharapkan pada siklus II akan terjadi penigkatan yang signifikan.

\section{Siklus II}

Hasil test pada siklus II ini, jumlah siswa yang menjadi subjek penelitian 17, siswa tuntas belajar (nilai minimal sama dengan KKM yakni 70) 15 siswa $(88 \%)$ dan siswa tidak tuntas 2 siswa (12\%). Selanjutnya, dari 17 siswa kategori sangat baik sebanyak 4 siswa (24\%), kategori baik sebanyak 4 siswa (24\%), kategori lebih dari cukup sebanyak 6 siswa (35\%), kategori cukup sebanyak 1 siswa (6\%), kategori kurang sebanyak 2 siswa (12\%). Rata-rata siswa yang dapat dicapai 85, modus berada pada nilai lebih dari cukup (80) sebanyak 6 siswa (35\%). Hasil pengamatan menunjukkan 14 siswa (82\%) siswa aktif dan 3 siswa (18\%) siswa pasif pada pertemuan I dan 16 siswa aktif dan 1 siswa pasif. Dengan demikian ada 94\% siswa aktif dan 6\% siswa pasif pada pertemuan II. Dengan demikian maka jumlah siswa aktif dari pertemuan I ke pertemuan II pada siklus II sebanyak 2 siswa (12\%)

Hasil refleksi yang diperoleh dari pelaksanaan siklus II disimpulkan kegitan pembelajaran berlangsung lebih efektif karena siswa terlihat semakin memahami cara belajar dengan menggunakan model pembelajaran Group Investigation (GI), kelas lebih kondusif, interaksi dalam kelompok telah berlangsung secara wajar, dan siswa dapat menyelesaikan tugas sesuai dengan waktu yang disediakan.

Perbandingan hasil belajar siswa pada siklus I dan siklus II, pada siklus I Siswa tuntas mencapai 14 siswa (82\%), sedangkan pada siklus II juga menunjukkan angka yang sama, yakni mencapai 15 siswa (88\%). Dengan demikian ada kenaikan ketuntasan belajar dari siklus I dan siklus II yaitu 1 siswa (6\%). Pada siklus I nilai rata-rata siswa mencapai 78 dan pada siklus II mencapai 85, terjadi kenaikan sebesar 7 poin. Berdasarkan data terjadi peningkatan prestasi belajar, baik pada fase pra siklus, siklus I, dan pada proses pembelajaran padasiklus II. Dengan demikian model pembelajaran Complete centence merupakan salah satu model pembelajaran yang dapat dijadikan sebagai suatu referensi dalam kegiatan pebelajaran untuk meningkatkan aktifitas siswa dalam belajar.

\section{KESIMPULAN}

Hasil penelitian yang dilakukan sebanyak 2 siklus membuktikan bahwa penggunaan model pembelajaran Group Investigation (GI) dapat meningkatkan prestasi belajar siswa yang ditandai dengan adanya peningkatan prosentase ketuntasan belajar siswa dan nilai rata-rata kelas. Pada siklus I tingkat ketuntasan mencapai $82 \%$ dan pada siklus II naik menjadi $88 \%$. Kemudian untuk nilai ratarata kelas, pada siklus I mencapai 78 dan nilai rata-rata kelas pada siklus II naik menjadi 85. Dengan demikian dapat disimpulkan bahwa model pembelajaran 
Group Investigation (GI) dapat meningkatkan prestasi belajar IPA pada siswa kelas V semester I tahun pelajaran 2014/2015 di SDN 1 Ngembel Kecamatan Watulimo Kabupaten Trenggalek.

\section{SARAN}

Berdasarkan keseluruhan proses dan hasil penelitian, disarankan bahwa penggunaan model pembelajaran Group Investigation (GI) memerlukan persiapan yang cukup matang, sehingga guru harus benar-benar mempersiapkan segala sesuatunya dengan matang pula, baik media maupun alat evalusinya; untuk terus meningkatkan prestasi belajar siswa hendaknya guru menggunakan model pembelajaran yang bervariasi dan menarik, sehingga tidak menimbulkan kebosanan pada diri siswa dalam melaksanakan kegiatan belajar, dan hendaknya guru dapat memilih model pembelajaran yang sesuai dengan karakteristik materi dan karakteristik siswa, sehingga penanaman konsep benar-benar dapat diterima oleh siswa dengan baik.

\section{DAFTAR RUJUKAN}

Arikunto, Suharsimi. 2011. Penelitian Tindakan Kelas. Jakarta. BumiAksara

Asrori, Mohamad. 2011 Psikologi Pembelajaran.Bandung; Wacana Prima

Aqib, Zainal. 2012. Profesionalisme Guru dalam Pembelajaran. Surabaya: Insan Cendekia

Depdikbud. 2006. Kurikulum Tingkat Satuan Pendidikan Sekolah Dasar. Jakarta:Dinas Pendidikan dan Kebudayaan.

Djamarah, Syaiful Bahri.2011. Psikologi Belajar: Jakarta: Rineka Cipta

Fajri, Em Zul. 2008. Kamus Lengkap Bahasa Indonesia. Diffa Publisher

Fathurrohman, Muhammad.2012. Belajar dan Pembelajaran.Yogyakarta: Teras

Maufur, Fauzi.2009. Sejuta jurus mengajar Mengasyikkan. Semarang: Sindu Press.

Shoimin, Aris. 2014. 68 Model Pembelajaran Inovatif dalam Kurikulum 2013.Yogyakarta:Ar-Ruzz Media.

Sukidin. 2012. Manajemen Penelitian Tindakan Kelas. Surabaya:Insan Cendekia.

Uno, Hamzah B. 2008. Teori Motivasi dan Pengukurannya. Jakarta: Bumi Aksara 